\title{
Severe neurological complications in critically ill COVID-19 patients
}

\author{
Quirin Notz ${ }^{1}$ (D) Christopher Lotz ${ }^{1} \cdot$ Johannes Herrmann $^{1} \cdot$ Marius Vogt $^{2} \cdot$ Tobias Schlesinger $^{1} \cdot$ Markus Kredel $^{1}$. \\ Wolfgang Muellges ${ }^{3} \cdot$ Dirk Weismann $^{4} \cdot$ Thomas Westermaier $^{5} \cdot$ Patrick Meybohm $^{1} \cdot$ Peter Kranke $^{1}$
}

Received: 3 June 2020 / Revised: 5 August 2020 / Accepted: 7 August 2020 / Published online: 14 August 2020

(c) The Author(s) 2020

\section{Dear Sirs,}

A 56-year-old male patient was admitted to a secondary care hospital 7 days after the onset of fever and coughing. COVID-19 was confirmed and the patient was intubated after rapid respiratory deterioration. He was transferred to our tertiary care center and admitted to the intensive care unit (ICU). The patient suffered from a severe acute respiratory distress syndrome (ARDS, $\mathrm{p}_{\mathrm{a}} \mathrm{O}_{2} / \mathrm{F}_{\mathrm{i}} \mathrm{O}_{2} 64 \mathrm{mmHg}$ [15], Fig. 1c, d), septic shock [17] and acute renal failure. He received low-dose acetylsalicylic acid (ASA) and therapeutic anticoagulation with unfractionated heparin (activated partial thromboplastin time, aPTT, in the range of 43-76 s). Over the next few days, the pulmonary gas exchange and other organ functions ameliorated. On day 18 , however, routine clinical examination revealed a unilateral, dilated and unresponsive pupil, which lead to an immediate cranial computed tomography (cCT). The cCT showed excessive bilateral parieto-occipital parenchymal bleeding, as well as left frontal, temporal and parafalcine subdural hemorrhage with subfalcine herniation and midline shifting of $>1 \mathrm{~cm}$ to the right, hydrocephalus and signs of massively increased intracerebral pressure (Fig. 1a, b). Following the cCT scan, his clinical status rapidly deteriorated with both pupils wide and unresponsive to light. The patient was considered to

Patrick Meybohm

meybohm_p@ukw.de

1 Department of Anesthesiology and Critical Care, University Hospital Wuerzburg, Wuerzburg, Germany

2 Department of Diagnostic and Interventional Neuroradiology, University Hospital Wuerzburg, Wuerzburg, Germany

3 Department of Neurology, University Hospital Wuerzburg, Wuerzburg, Germany

4 Department of Internal Medicine I, University Hospital Wuerzburg, Wuerzburg, Germany

5 Department of Neurosurgery, University Hospital Wuerzburg, Wuerzburg, Germany have irreversible brain damage. As such, surgical decompression or osmotherapy was not an option and palliative care was initiated. The patient died a few hours later.

The aim of this case series is to review neurologic findings in high-risk intensive care patients suffering from moderate to severe COVID-19 induced ARDS. Furthermore, we will discuss the difficulty to decipher specific neurologic features of COVID-19 from epiphenomena of critical illness and the need for additional data on neurologic sequelae of COVID-19.

Reviewing all 38 COVID-19 patients admitted to our ICU between March 20th and May 27th 2020, we found neurological complications in nine (23.7\%) cases (Table 1). Affected patients had a median age of 56 years (54-66), 66.7\% were male and $33.3 \%$ female, median $\mathrm{pO}_{2} / \mathrm{FiO}_{2}$ ratio at admission was $157 \mathrm{mmHg}(127-183)$. Seven patients had potentially life-threatening neurological events (18.4\%), which in two cases occurred during veno-venous extracorporeal membrane oxygenation (ECMO) therapy. One patient died in consequence of the neurological complication (2.6\%). Including the aforementioned case report, three patients suffered from intracerebral hemorrhage. A subarachnoid hemorrhage occurred in a tri-cytopenic patient with a history of stem cell transplant. Another patient showed multiple small intracerebral bleedings of septic-embolic etiology. Two patients had first-time generalized seizures, likely due to septic encephalitis and two suffered from transient paresis and aphasia. Ischemic insults were not confirmed.

COVID-19 patients are threatened by ARDS and ICU treatment is required in approximately five percent of the cases $[4,9]$. Stabilizing cardiopulmonary function is challenging; however, the success of intensive care and quality of life is often determined by the neurocognitive and neuromuscular function. Acute ischemic stroke, intracerebral bleeding and encephalitis have all been described in ARDS patients and long-term cognitive impairment is a major issue for $20 \%$ of ARDS survivors after 5 years [6]. Pathophysiologic changes contributing to neurological complications include hyperinflammation, blood-brain-barrier 
Fig. 1 Imaging (CT) of the patient in the case report. a Bilateral hemorrhage in the parietooccipital parenchyma featuring fluid-fluid levels and left-hemispheric subdural hematoma. Considerable mass effect resulting in significant midline shift to the right as well as transtentorial and subfalcine herniation. b Right-sided subarachnoidal hemorrhage adjacent to small intraparenchymal bleeding. c, d Extensive ground glass opacities predominantly in the periphery of both lungs and dorsal air space consolidation
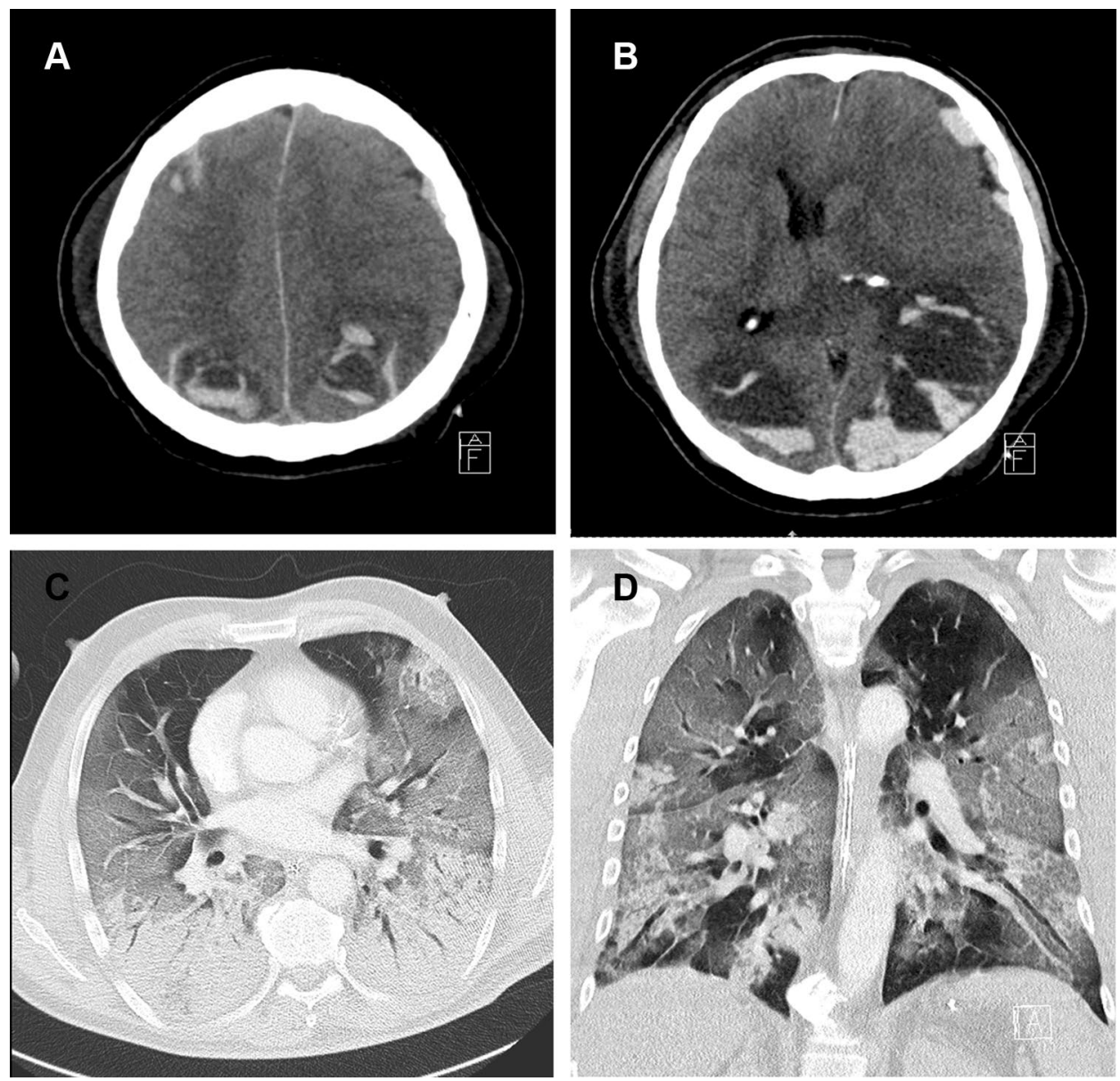

dysfunction, hypoperfusion and difficulties of mechanical ventilation [16]. Also, structural brain damage and neurological deterioration has been reported in 7\% of non-COVID-19 patients following ECMO therapy [10].

In COVID-19, hypercoagulability and a high incidence of thromboembolism are additional problems [8, 14]. Intensivists are caught between Scylla and Charybdis: Hypercoagulability bears the risk of pulmonary embolism, stroke or cerebral infarction and prompts us to utilize therapeutic anticoagulation and low-dose ASA in all COVID-19 patients. On the other hand, a substantial risk of intracerebral hemorrhage needs to be considered.

It is unclear, whether the observed neurological events are sole epiphenomena of critical illness, or rather directly relate to the severe acute respiratory syndrome coronavirus 2 (SARS-CoV2) infection. In fact, data regarding the incidence of neurological complications in COVID-19 are scarce $[2,11]$ and the precise pathophysiology of SARS$\mathrm{CoV} 2$ viral spread remains largely unknown. Corona viruses are neurotropic [3] and sudden loss of smell or taste can be early clinical signs [1]. Vascular alterations have been described in autopsies of COVID-19 patients and may also contribute to neurological manifestations and bleeding complications [12]. Few case series have described neurologic changes in COVID-19. Findings mainly include encephalopathy, encephalitis and changes in mental status, all of which might not be specific for COVID-19 [5, 7]. Nevertheless, early recognition of viral encephalitis, acute cerebrovascular disease and neural system damage seems critical, not only for short-term survival but long-term quality of life.

Despite a relatively high incidence of events compared to other ICU patients [13], our observations so far do not pinpoint towards COVID-19-specific neurological complications. This study highlights the importance of a careful use of full intense anticoagulation. We still believe, that the benefits of therapeutic anticoagulation outweigh the risk of severe intracerebral hemorrhage. However, many aspects of COVID-19 remain uncharted and the sheer number of patients requiring long-term neurologic care will provide a burden to all health care systems in the years to come. 
Table 1 Neurological manifestations of critically ill COVID-19 patients $(n=38)$

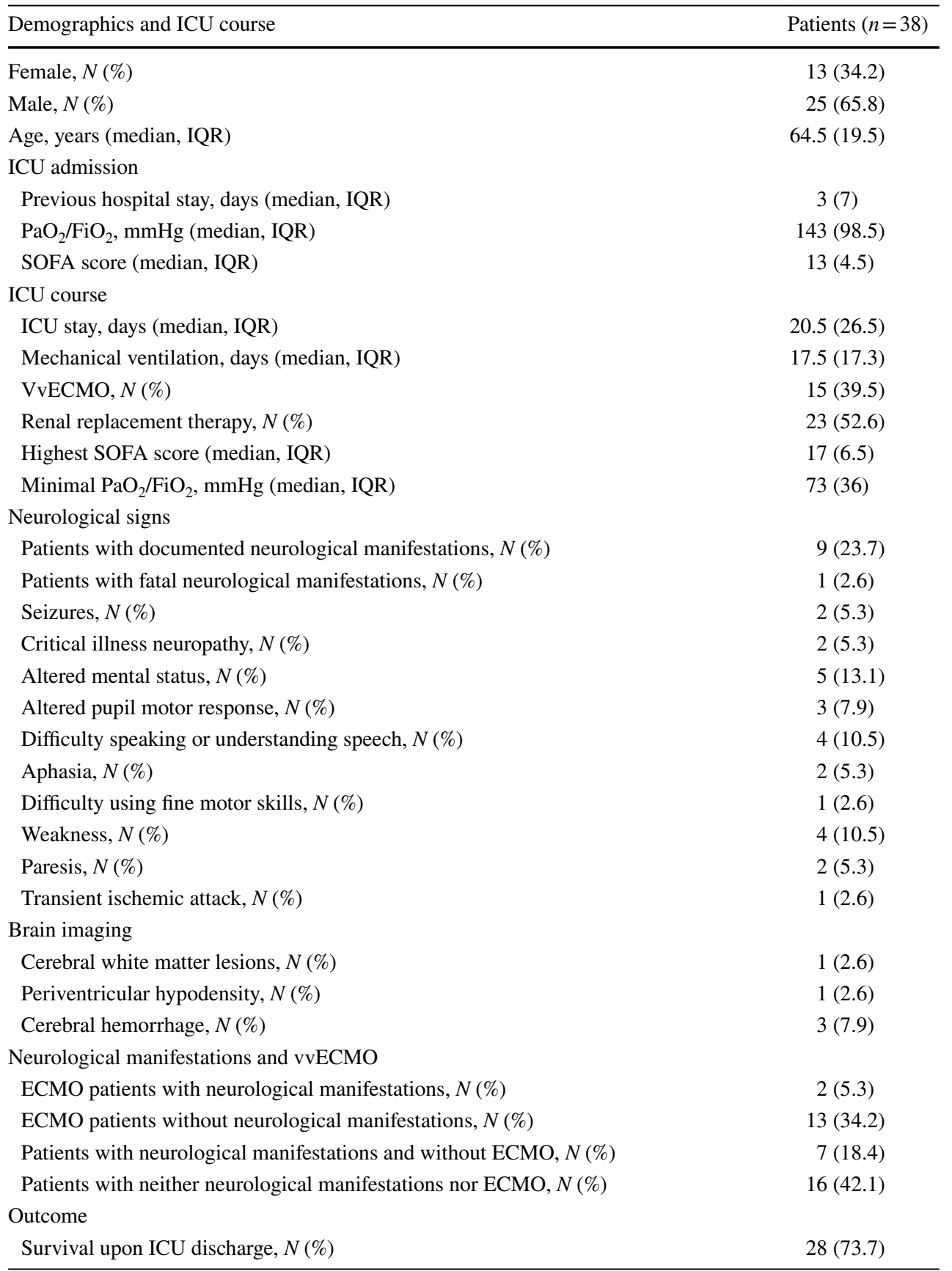

$I C U$ intensive care unit, IQR interquartile range, $\mathrm{N}$ number of patients, $\mathrm{PaO}_{2} / \mathrm{FiO}_{2}$ ratio of arterial oxygen partial pressure and fraction of inspired oxygen (Horovitz index), SOFA sequential organ failure assessment, $v v E C M O$ veno-venous extracorporeal membrane oxygenation
Acknowledgments Open Access funding provided by Projekt DEAL.

\section{Compliance with ethical standards}

Conflicts of interest On behalf of all authors, the corresponding author states that there is no conflict of interest.
Ethical approval The institutional ethic board of the University of Wuerzburg waived the need for a specific approval due to the context of sole retrospective chart review within standard care $(63 / 20-\mathrm{kr}$ 25.03.2020). The legal representative of the patient from the case report has consented to the submission of this article to the journal. 
Open Access This article is licensed under a Creative Commons Attribution 4.0 International License, which permits use, sharing, adaptation, distribution and reproduction in any medium or format, as long as you give appropriate credit to the original author(s) and the source, provide a link to the Creative Commons licence, and indicate if changes were made. The images or other third party material in this article are included in the article's Creative Commons licence, unless indicated otherwise in a credit line to the material. If material is not included in the article's Creative Commons licence and your intended use is not permitted by statutory regulation or exceeds the permitted use, you will need to obtain permission directly from the copyright holder. To view a copy of this licence, visit http://creativecommons.org/licenses/by/4.0/.

\section{References}

1. Abalo-Lojo JM, Pouso-Diz JM, Gonzalez F (2020) Taste and smell dysfunction in COVID-19 patients. Ann Otol Rhinol Laryngol. https://doi.org/10.1177/0003489420932617

2. Asadi-Pooya AA, Simani L (2020) Central nervous system manifestations of COVID-19: a systematic review. J Neurol Sci 413:116832

3. Bohmwald K, Gálvez NMS, Ríos M, Kalergis AM (2018) Neurologic alterations due to respiratory virus infections. Front Cell Neurosci 12:386

4. Guan WJ, Ni ZY, Hu Y, Liang WH, Ou CQ, He JX, Liu L, Shan H, Lei CL, Hui DSC, Du B, Li LJ, Zeng G, Yuen KY, Chen RC, Tang CL, Wang T, Chen PY, Xiang J, Li SY, Wang JL, Liang ZJ, Peng YX, Wei L, Liu Y, Hu YH, Peng P, Wang JM, Liu JY, Chen Z, Li G, Zheng ZJ, Qiu SQ, Luo J, Ye CJ, Zhu SY, Zhong NS (2020) Clinical characteristics of coronavirus disease 2019 in China. N Engl J Med 382:1708-1720

5. Helms J, Kremer S, Merdji H, Clere-Jehl R, Schenck M, Kummerlen C, Collange O, Boulay C, Fafi-Kremer S, Ohana M, Anheim M, Meziani F (2020) Neurologic features in severe SARS-CoV-2 infection. N Engl J Med 382:2268-2270

6. Herridge MS, Moss M, Hough CL, Hopkins RO, Rice TW, Bienvenu OJ, Azoulay E (2016) Recovery and outcomes after the acute respiratory distress syndrome (ARDS) in patients and their family caregivers. Intensive Care Med 42:725-738

7. Holmes EA, O'Connor RC, Perry VH, Tracey I, Wessely S, Arseneault L, Ballard C, Christensen H, Cohen Silver R, Everall I, Ford T, John A, Kabir T, King K, Madan I, Michie S, Przybylski AK, Shafran R, Sweeney A, Worthman CM, Yardley L, Cowan K, Cope C, Hotopf M, Bullmore E (2020) Multidisciplinary research priorities for the COVID-19 pandemic: a call for action for mental health science. Lancet Psychiatry 7:547-560

8. Klok FA, Kruip MJHA, van der Meer NJM et al (2020) Incidence of thrombotic complications in critically ill ICU patients with COVID-19. Thromb Res. 191:145-147. https://doi.org/10.1016/j. thromres.2020.04.013

9. Livingston E, Bucher K (2020) Coronavirus disease 2019 (COVID-19) in Italy. JAMA. https://doi.org/10.1001/ jama.2020.4344

10. Lorusso R, Gelsomino S, Parise O, Di Mauro M, Barili F, Geskes G, Vizzardi E, Rycus PT, Muellenbach R, Mueller T, Pesenti A, Combes A, Peek G, Frenckner B, Di Nardo M, Swol J, Maessen J, Thiagarajan RR (2017) Neurologic injury in adults supported with veno-venous extracorporeal membrane oxygenation for respiratory failure: findings from the extracorporeal life support organization database. Crit Care Med 45:1389-1397

11. Mao L, Jin H, Wang M et al (2020) Neurologic manifestations of hospitalized patients with coronavirus disease 2019 in Wuhan, China. JAMA Neurol. 77(6):1-9. https://doi.org/10.1001/jaman eurol.2020.1127

12. Menter T, Haslbauer JD, Nienhold R et al (2020) Postmortem examination of COVID-19 patients reveals diffuse alveolar damage with severe capillary congestion and variegated findings in lungs and other organs suggesting vascular dysfunction. Histopathology. https://doi.org/10.1111/his.14134

13. Ortega-Gutierrez S, Wolfe T, Pandya DJ, Szeder V, Lopez-Vicente M, Zaidat OO (2009) Neurologic complications in non-neurological intensive care units. Neurologist 15:254-267

14. Panigada M, Bottino N, Tagliabue P et al (2020) Hypercoagulability of COVID-19 patients in intensive care unit: a report of thromboelastography findings and other parameters of hemostasis. J Thromb Haemost. 18(7):1738-1742. https://doi.org/10.1111/ jth. 14850

15. Ranieri VM, Rubenfeld GD, Thompson BT, Ferguson ND, Caldwell E, Fan E, Camporota L, Slutsky AS (2012) Acute respiratory distress syndrome: the Berlin Definition. JAMA 307:2526-2533

16. Sasannejad C, Ely EW, Lahiri S (2019) Long-term cognitive impairment after acute respiratory distress syndrome: a review of clinical impact and pathophysiological mechanisms. Critical Care (Lond, Engl) 23:352

17. Singer M, Deutschman CS, Seymour CW, Shankar-Hari M, Annane D, Bauer M, Bellomo R, Bernard GR, Chiche JD, Coopersmith CM, Hotchkiss RS, Levy MM, Marshall JC, Martin GS, Opal SM, Rubenfeld GD, van der Poll T, Vincent JL, Angus DC (2016) The third international consensus definitions for sepsis and septic shock (sepsis-3). JAMA 315:801-810 